\title{
Primary cutaneous malignant melanoma metastatic to the iris
}

\author{
LAWRENCE W. HIRST, JOSEPH REICH, AND J. E. K. GALBRAITH \\ From the Royal Melbourne Hospital, Australia
}

SUMMARY We describe a case of cutaneous malignant melanoma metastatic to the iris as the first presenting sign of metastases 10 years after excision of the primary tumour. The histology of the excised iris metastases and the primary skin melanoma are compared. Progressive intracranial metastatic growth did not correlate with the observed regression of the residual intraocular melanoma cells during cyclical cytotoxic therapy.

Iris metastases from primary cutaneous malignant melanomas are rare, with only 4 pathologically proved cases (Wagenmann, 1900; Adamük, 1909; Font et al., 1967). One case describing the response of intraocular cutaneous-melanoma metastases to cytotoxic agents has been reported (Stark et al., 1971). Our case illustrates a 10-year metastasis-free interval after primary cutaneous tumour excision and then seeding only to the distribution of the internal carotid artery. The intracranial metastases progressed despite the dramatic regression of residual metastatic intraocular tumour cells in response to cytotoxic therapy.

\section{Case report}

A 26-year-old white woman presented in November 1975 with a 5-week history of blurred vision in her left eye and accompanying headaches. On examination her visual acuity was $6 / 4$ and $6 / 5$ in the right and left eye respectively. There was a pale, fleshy mass of $2 \mathrm{~mm}$ diameter in the anterior stroma of the iris superonasally in the left eye. It was situated at the collarette and slightly peaked the pupil in this quadrant. Many large pigmented cells were circulating in the anterior chamber, and similar cells were distributed in a fern-like pattern on the anterior lens capsule and on the central corneal endothelium. Applanation tonometric pressures were $17 \mathrm{mmHg}$ in both eyes, and both angles were grade $4 / 4$ on gonioscopy, with no abnormal pigmentation present. The vitreous and fundus were normal.

Physical examination revealed a skin graft on the left scapular area and no clinical evidence of meta-

Address for reprints: Dr L. W. Hirst, Wilmer Institute, Johns Hopkins Hospital, Baltimore, Maryland 21205, USA stases. Computerised axial tomography and liver and spleen scans gave normal results. Chest $x$-rays showed a left hilar mass which had not changed in size since it had first been reported 3 years previously on routine tuberculosis screening.

The patient gave a history of having had excision of a malignant melanoma of her left scapular area at the Westminster Hospital, London, 10 years previously. The tumour had been totally excised, and no metastases were found clinically or on radiological examination at that time.

In December 1975, 3 weeks after ocular examination, the iris lesion was excised through a corneoscleral limbal section nasally and a sector iridectomy. Histological examination of the excised iris lesion showed a well circumscribed malignant melanoma metastasis. Postoperatively there was an increase of pigmented cells in the anterior chamber, with visible deposition of cells on the anterior lens capsule and prominently on the lens equator nasally. Through the sector iridectomy it was now possible to see another pigmented mass adjacent to the area of lens involvement. The mass abutting the lens nasally was considered to originate probably in the ciliary body.

One month after operation chemotherapy was begun with dicarbamazine, $500 \mathrm{mg} /$ day intravenously for 5 days; hydroxyurea, $2 \mathrm{~g}$ /day for 5 days; and BCG vaccination (Commonwealth Serum Laboratories), $75 \mathrm{mg} / \mathrm{ml}$ on days 14 and 21 of the course. Within 4 days of initiating chemotherapy the intense cellular activity in the anterior chamber and cell deposition on the lens diminished markedly to only an occasional circulating cell. The intraocular pressure, which had risen to $18 \mathrm{mmHg}$ postoperatively, now dropped rapidly to $10 \mathrm{mmHg}$.

Two months after operation, however, the patient presented with a grand mal seizure. Cellular activity 
in the anterior chamber was again much increased. Dynamic and static brain scans, computerised axial tomography, and electroencephalogram were within normal limits. The hilar mass remained unchanged. Once again she was given a course of cytotoxic agents like the previous one, and within 4 days the cellular activity in the anterior chamber again diminished to an occasional circulating cell. Her vision could be corrected to $6 / 9$ in the left eye, and the intraocular pressure was $12 \mathrm{mmHg}$.

Three months after operation a third course of cyclical combined chemotherapy with dicarbamazine and hydroxyurea and BCG was begun. Within 5 days the cellular activity in the anterior chamber, which had slowly increased over the preceding month, dramatically abated. At this time her vision was $6 / 6$, and her intraocular pressure was $25 \mathrm{mmHg}$. The increased pressure was unresponsive to acetazolamide, and gonioscopy showed a heavily pigmented angle with cells similar to those circulating in the anterior chamber and deposited on the lens capsule.

Four months after operation the patient was admitted to hospital with mental confusion, headaches, and vomiting. A brain scan showed probable secondary deposits of melanoma. Despite steroid therapy her condition deteriorated, and she died 5 days after admission. Necropsy revealed multiple intracranial melanotic deposits but no other evidence of extraocular metastasis. Permission for ocular enucleation was refused by the family.

\section{Discussion}

Ocular metastasis from primary cutaneous malignant melanoma is uncommon, with 33 pathologically proved cases reported (Landesberg, 1869; Brömser, 1870; Schiess-Gemuseus and Roth, 1879; Pflüger, 1885; Wagenmann, 1900; Jensen, 1906; Adamük, 1909; Uhler, 1914; Ten Doesschate, 1921; Boente, 1929; Cordes and Horner, 1930; Corrado, 1931; Fry, 1933; Kreibig, 1935; Wilder, 1946; Jensen, 1957; Liddicoat et al., 1959; Riffenburgh, 1961; Covell and Markiewitz, 1961; Das Gupta and Brasfield, 1964; Font et al., 1967; Szeps and Patterson, 1969; Stark et al., 1971; Ferry, 1972; Günther, 1973; Kremlicka et al., 1974; Fishman et al., 1976). Only 5 of those cases showed iris involvement (Wagenmann, 1900; Adamük, 1909; Font et al., 1967; Stark et al., 1971). Intraocular metastases were most commonly to the choroid.

The present case illustrates one of the few clinical situations where excisional biopsy of a solitary iris nodule is indicated for diagnostic purposes. The diagnosis of this iris nodule as a first manifestation of malignant melanoma metastases 10 years after the primary excision, together with negative brain, lung, and bone scans, was unexpected. The possibility that the nodule was either a primary melanoma of the iris or a secondary deposit from another occult neoplasm had to be considered. The early diagnosis of metastasis from cutaneous malignant melanoma or from another occult primary neoplasm was essential for treatment. Because of its accessible location the nodule was excised by a sector iridectomy, with histological proof of excision beyond the tumour margin. The histological report defined the nodule as showing a thickening of the iris stroma by a malignant melanoma near the pupil. The growth was not encapsulated, but it was reasonably well circumscribed and appeared to have been totally removed surgically. The malignant cells, which were of epithelioid type, were strikingly uniform in size and configuration and were grouped in conspicuous acini (Figs. 1 and 2). A few of the

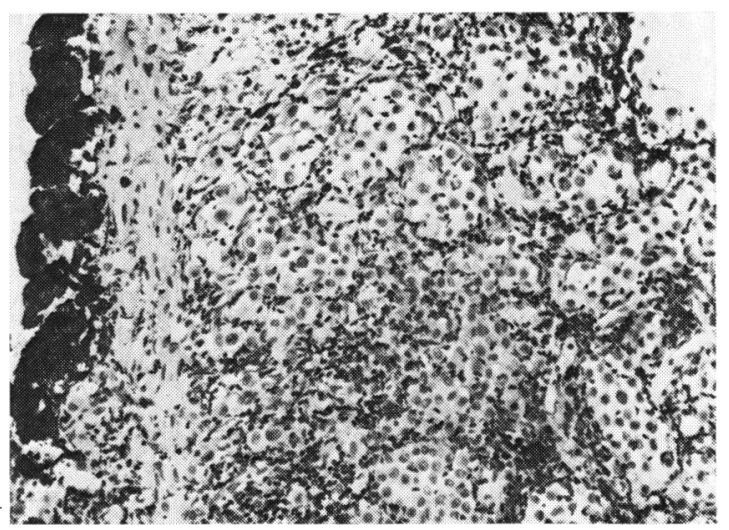

Fig. 1 Part of iris metastasis showing round-cell infiltrate and alveolar formation of epithelioid melanocytes in the iris stroma. $H$. and $E ., \times 85$

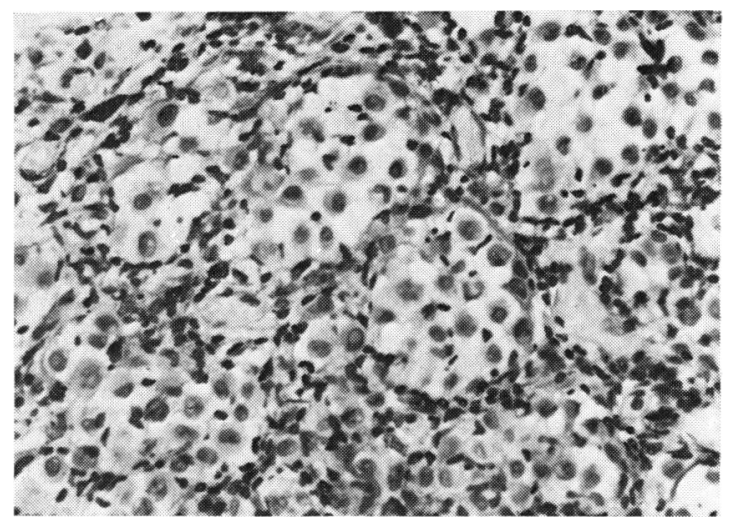

Fig. 2 Details of epithelioid melanocytes in iris stroma. $H$. and $E$., $\times 180$ 
cells contained melanin in the form of fine granules. The uniformly epithelioid character of the cells throughout the growth, in conjunction with the clinical features of the case, was strongly in favour of a metastatic malignant melanoma.

Re-examination of the primary cutaneous tumour sections showed melanoma cells of epithelioid type, arranged in alveoli at the dermal-epidermal junction. Nests of epithelioid melanocytes were seen separated by fine fibrous septa, and there was some streaming of melanocytes into the dermis.

Examination of this primary tumour showed the margins to be free of tumour tissue and with no evidence of local extension. The cell type and cell arrangement in the primary and secondary tumours were similar. Although the possibility that this iris nodule was a primary iris melanoma cannot be ruled out, the presence of cerebral melanoma metastases at necropsy within months of the emergence of the iris lesion strongly suggests that cutaneous malignant melanoma was the source of all the melanoma deposits.

Intraocular tumours, whether primary or metastatic, that simulate iridocyclitis have been well described (Zimmerman 1968). In the present case after the sector iridectomy a probable ciliary-body metastasis was visualised and it continued to shed cells into the anterior chamber with deposition in the angle and on the anterior lens capsule. The dramatic decrease in cellular activity in the anterior chamber within 4 days of beginning 3 consecutive courses of chemotherapy was achieved without any topical administration of drugs. This may represent the earliest documented in-vivo response of malignant melanoma metastases to chemotherapy. This apparent responsiveness of the metastases to the combined chemotherapy supports previous reports that systemic cytotoxic agents are effective against intraocular melanoma metastases (Stark et al., 1971).

It is probable that the intraocular and intracranial metastases occurred simultaneously even though initial computerised axial tomography of the brain was negative. An intracranial nodule of similar size to the $2 \mathrm{~mm}$-diameter iris mass would have been well below tomography resolution threshold. However, apparent response to cytotoxic therapy of the residual exfoliated melanoma cells in the eye was not paralleled by involution of the intracranial metastases, which continued to enlarge. This paradox can perhaps be explained by many factors - including the level of local drug distribution in the tissues, metastatic cellular cohesion properties, and the tumour mass.

Metastasis of malignant melanoma from the skin to the central nervous system exclusively is rare
(Pennington and Milton, 1975). Intracranial metastases from the skin would suggest spread via the internal carotid system, which explains also the intraocular involvement. The location of the intraocular metastases in the iris would also indicate direct arterial embolisation, as shown by tumour seeding experiments that show preferential anteriorsegment involvement (Albert et al., 1967). This, however, is in contrast to the majority of actual intraocular sites of metastases in necropsy findings (Ferry and Font, 1974).

The rapid deterioration in the patient's clinical condition after the appearance of the first metastasis is consistent with the known behaviour of intracranial malignant melanoma metastases (Pennington and Milton, 1975).

We thank Dr C. H. Greer, Royal Victorian Eye and Ear Hospital, Melbourne, and Dr Prithi Bhathal, Department of Pathology, University of Melbourne, for the report and photomicrographs of the iris lesion; Mr Westbury, consultant surgeon, Westminster Hospital, London, for the patient's history and for biopsy sections of the primary cutaneous melanoma, and Mr J. David Andrews, Wilmer Institute, Baltimore, for reviewing the manuscript.

\section{References}

Adamük, V. (1909). Ein Fall von metastatischen Melanosarkom der Uvea. Zeitschrift fïr Augenheilkunde, 21, 505 .

Albert, D. N., Zimmermann, A. W., Jr., and Zeidman, I. (1967). Tumour metastasis to the eye. Part III. The fate of circulating tumour cells to the eye. American Journal of Ophthalmology, 63, 733-738.

Boente, R. (1929). Metastatische Melanoblastome in der Retina. Klinische Monatsblätter für Augenheilkunde, 82, 732-740.

Brömser (1870). Ueber einen Fall von sekundärem Melanom der Choroidea. Inaug. Diss., Berlin, 1870; cited by Leber, T., Bemerkung zu der vorhergehenden Mittheilung. Albrecht von Graefes Archiv fïr Ophthalmologie, 1885, 31, 111-114.

Cordes, F. C., and Horner, W. D. (1930). Metastatic melanoma of both eyes. Journal of the American Medical Association, 95, 655-658.

Corrado, A. (1931). Sul sarcoma metastatico del corpo ciliare. Archivio di Ottalmologia, 38, 508-527.

Covell, L. L., and Markiewitz, H. H. (1961). The choroid as site of prime manifestation of systemic involvement in skin melanoma. American Journal of Ophthalmology, 51, 12961303.

Das Gupta, T., and Brasfield, R. (1964). Metastatic melanoma. Cancer, 17, 1323-1339.

Ferry, A. P. (1972). Primary malignant melanoma of the skin metastatic to the eye. American Journal of Ophthalmology, 74, 12-19.

Ferry, A. P., and Font, R. L. (1974). Carcinoma metastatic to the eye and orbit: I. A clinocopathologic study of 227 cases. Archives of Ophthalmology, 92, 276-286.

Fishman, M. L., Tomaszewski, M. M., and Kuwabara, T. (1976). Malignant melanoma of the skin metastatic to the eye: frequency in autopsy series. Archives of Ophthalmology, 94, 1309-1311.

Font, R. L., Naumann, G., and Zimmerman, L. E. (1967). 
Primary malignant melanoma of the skin metastatic to the eye and orbit: report of ten cases and review of the literature. American Journal of Ophthalmology, 63, 738754.

Fry, W. E. (1933). Metastatic sarcoma of the choroid. Archives of Ophthalmology, 9, 248-255.

Günther, I. (1973). Augenmetastasen beim malignen Melanom der Haut. Klinische Monatsblätter für Augenheilkunde, 162, 821-823.

Jensen, E. (1906). Ein Fall von Sarkommetastase in beiden Augen. Klinische Monatsblätter für Augenheilkunde, 44 (pt. 1), 580 (abstract).

Jensen, O. A. (1957). Choroid metastasis from a malignant melanoma of the skin. Acta Ophthalmologica, 35, 91-96 (suppl. 46).

Kreibig, W. (1935). Zur Kenntnis intraokulärer Sarkommetastasen. Zeitschrift für Augenheilkunde, 87, 265-284.

Kremlicka, L., Roubkova, H., and Cerna, T. (1974). A case of ocular metastasis of primary malignant melanoma of the skin. Ceskoslovenska Oftalmologie, 30, 119-122.

Landesberg (1869). Casuistische Mittheilungen. III. Sarcom der Chorioidea. Albrecht von Graefes Archiv für Ophthalmologie, 15, 210-214.

Liddicoat, D. A., Wolter, J. R., and Wilkinson, W. C. (1959). Retinal metastasis of malignant melanoblastoma. American Journal of Ophthalmology, 48, 172-177.

Pennington, D. G., and Milton, G. W. (1975). Cerebral metastasis from melanoma. Australian and New Zealand Journal of Surgery, 45, 405-409.
Pflüger, W. (1885). Metastatisches Sarcom der Chorioidea. Archiv für Augenheilkunde, 14, 129-132.

Riffenburgh, R. S. (1961). Metastatic malignant melanoma to the retina. Archives of Ophthalmology, 66, 487-489.

Schiess-Gemuseus, and Roth, M. (1879). Metastatisches Sarkom der Papille und angrenzenden Retina. Albrecht von Graefes Archiv für Ophthalmologie, 25, 177-190.

Stark, W. J., Rosenthal, A. R., Mullins, G. M., and Green, W. R. (1971). Simultaneous bilateral uveal melanomas responding to BCNU therapy. Transactions of the American Academy of Ophthalmology and Otolaryngology, 75, 70-83.

Szeps, J., and Patterson, T. D. (1969). Metastatic malignant melanoma of ciliary body and choroid from a primary melanoma of skin. Canadian Journal of Ophthalmology, 4, 394-399.

Ten Doesschate, G. (1921). Ueber metastatisches Sarkom des Auges. Klinische Monatsblätter für Augenheilkunde, 66, 766 (abstract).

Uhler, E. M. (1914). Metastatic malignant melanoma of the retina. American Journal of Ophthalmology, 23, 158-162.

Wagenmann, D. (1900). Ein Fall von multiplen Melanosarkomen mit eigenartigen Komplikationen beider Augen. Deutsche medizinische Wochenschrift, 26, 262-263.

Wilder, H. C. (1946). Intraocular tumours in soldiers: World War II. Military Surgeon, 99, 459-490.

Zimmerman, L. E. (1968). Role of the histopathologist in a uveitis program. In Clinical Methods in Uveitis: The Fourth Sloan Symposium on Uveitis, pp. 128-135. Edited by S. B. Aronson et al. Mosby: St. Louis. 